\title{
Board Composition and Diversification Decisions of UK Listed Companies: A Panel Data Analysis
}

Dr Michael McCann

Nottingham Business School

Nottingham Trent University

50 Shakespeare Street

Nottingham NG1 4FQ

Tel: +44(0)1158482451

Email: michael.mccann@ntu.ac.uk

Dr Michael McCann is a senior lecturer in Economics at Nottingham Business School. His research primarily concerns corporate governance, acquisitions and strategic decisionmaking. The particular focus is the role of the market for corporate control in corporate governance. He utilises both quantitative and qualitative research methods to analyse various aspects of the acquisition process and its aftermath. 


\title{
Board Composition and Corporate Diversification in UK Listed Companies: A Panel Data Analysis
}

\begin{abstract}
This paper investigates the link between the board composition and the corporate diversification decisions of 50 large UK listed corporations over the period from 2005 to 2015. The panel data analysis integrates changes in board composition and its dynamic effect on the extent of diversification. We find that increased board independence influences the extent of both unrelated and related diversification. Neither institutional representatives nor extraindustry interlocking directors influence the extent of diversification in ways which promote shareholders' interests. The findings supports corporate governance policy promoting board independence. In contrast, these findings suggest extending the involvement of institutional investors to board representation may not mitigate agency problems in large companies.
\end{abstract}

Key Words: Corporate governance, Board of Directors, Diversification, Strategy 


\section{Introduction}

This paper adds to the literature surrounding the governance role of corporate boards of directors by exploring the link between board composition and corporate diversification. In large joint stock companies, characterised by the separation of ownership and control, corporate governance mechanisms are intended to provide shareholders with some reassurance that managers will try to achieve outcomes that are in their interests (Shliefer and Vishny, 1997). With ongoing concerns about the effectiveness of such mechanisms, considerable academic research and policy discussions on corporate governance reform has centred on the role of corporate boards of directors (Adams et al. 2010). The work has produced a range of perspectives on the contribution of boards to corporate decision-making. Managerial hegemony theory suggests that boards are ineffective governance mechanisms, making little contribution to corporate decision-making (Pfeffer, 1972). Meanwhile, agency theory proposes that the corporate governance role of boards involves monitoring and discipline (Kaplan and Minton, 2006). Finally, stewardship theory argues that boards take an 'active' role in the management and control of corporations (Finkelstein and Hambrick, 1996; Walsh and Seward, 1990). These different perspectives have significant implications for the role of boards as effective corporate governance mechanisms and have influenced the policy debate as a result.

Corporate governance reform has emphasised the extent to which boards are independent of senior managers on the basis that such outside directors, acting as autonomous guardians of shareholder wealth, should ensure that resources are utilised effectively. For example, the most recent revision of the UK Corporate Governance Code (Financial Reporting Council, 2016, p. 10) states, “...the board should determine whether the director is independent in character and judgement and whether there are relationships or circumstances which are likely to affect, or could appear to affect, the director's judgement". To enhance the independence of boards, the UK Code expects a majority of board members in large companies to meet its definition. The 
is echoed in the US, where the listing requirements of both the New York Stock Exchange and the NASDAQ include requirements for a majority of independent directors on the board.

Unfortunately, the extensive work analysing the impact of board independence on performance has produced little positive evidence (McKnight and Weir, 2009; Nicholson and Kiel, 2007), and while other research indicates that such independent directors monitor and discipline senior managers (Chizema and Kim, 2010), there is scant evidence for their active involvement in formulating strategy, except in periods of crises (O’ Shannassy, 2010).

The literature highlights the extent of information asymmetry between independent directors and executive directors as the key factor determining the effectiveness of boards (Holmstrom, 2005). Access to information by independent directors is hampered by the limited time they can devote to a company (Fich and Shivdasani, 2006; McNulty and Pettigrew, 1999) and the reluctance of Chief Executive Officers (CEOs) to reveal it (Adams and Ferreira, 2007; Hermalin and Weisbach, 1998). Agency problems between shareholders and managers could be resolved by the presence of representatives of institutional ownership blocks on boards since they have an incentive to overcome information asymmetries and challenge management recommendations (Adams and Ferreira, 2007). Some evidence suggests that such behaviour by institutional investors is associated with improved performance (Clifford, 2008).

One area which could deepen knowledge of the influence of board composition on corporate governance is an analysis of its link with corporate diversification decisions. Corporate diversification is defined by Montgomery (1994) as participation in different markets. In the literature, a distinction is drawn between related and unrelated product diversification. Related diversification involves products where synergies arising from economies of scope exist. According to the resources approach, the ability of companies to exploit underutilised competences across related product markets enhances firm value (Rumelt, 1982). Meanwhile, 
unrelated diversification involves companies operating in very different product areas. Efficiency theory proposes that while investors should diversify their own portfolios across unrelated activities, in line with portfolio theory, it is wasteful if companies do it on their behalf. Consequently, unrelated diversification by companies is detrimental to shareholders' wealth (Amihud and Lev, 1981; Graham et al., 2002). Therefore, if boards were effective corporate governance mechanisms, then firms should pursue related product diversification and avoid unrelated product diversification.

This paper adds to the corporate governance literature on the role of boards by analysing the link between board composition and UK corporate diversification. The contributions include incorporating recent developments in board dynamics in the context of asymmetric information to develop hypotheses analysing whether the presence of directors with specific attributes can indicate their role in decision-making. Further, the paper incorporates a longitudinal aspect to the analysis which integrates changes in board composition and its dynamic effect on the extent of diversification. We also distinguish between the degree of related and unrelated diversification that firms conduct. Our findings imply that boards are active monitors, with the proportion of independent directors and their average length of tenure having a significant impact on both unrelated and related product diversification in the direction anticipated by agency theory. This suggests that, not only the presence of independent directors, but also, their cumulative experience of the company helps overcomes the asymmetric information they face. Since tenures can be short, we proposes that, in addition to increasing the proportion of independent directors on boards, encouraging longer tenures should produce more effective corporate governance.

The paper is structured as follows. The second section discusses existing theories which have conflicting views of the role of boards in corporate decision-making, incorporating recent developments regarding the role of boards in corporate strategy in the context of asymmetric 
information. We derive hypotheses proposing links between aspects of board composition and the extent of corporate diversification. Section 3 presents the sample, variables and empirical design. Section 4 presents the findings and discusses their implications. Section 6 is the conclusion.

\section{The Corporate Governance Role of Boards in Decision-making}

Corporate strategy defines an iterative process through which a corporation attempts to use the resources it controls to maximise value (Hendry and Kiel, 2004). Strategy will include identifying areas where resources would be used most efficiently. This will necessarily involve decisions surrounding the extent of diversification pursued by a firm. Where capital markets are highly liquid, shareholders have an ability to select and maintain a level of risk by holding a diversified portfolio of shares. As a result, they prefer companies to focus on related investments around the exploitation of core competences - termed related diversification (Rumelt, 1982). The corporate governance concern is that executive directors, in order to spread their firm-specific risk or 'empire-build' (Amihud and Lev, 1981; Jensen, 1986; Lane et al, 1998), may pursue unrelated diversification where there is little scope for the exploitation of core competences. The implication for the role of boards as effective corporate governance mechanisms is to ensure diversification decisions maximise value, increasing the extent of related diversification and avoiding unrelated diversification.

Since boards are endogenous (all companies have them), empirical work focuses on structural differences across boards which are anticipated to capture differences in behaviour, and hence their role, if any, in corporate governance. CEO-Chairman duality, board size, staggered boards, board appointments, board diversity and composition are some of the structural features which have been analysed in the literature (see Adams et al., 2005; Adams and Ferreira, 2007; 
Goyal and Park, 2002; Guo et al., 2008; Tian and Twite, 2011; Yermack, 1996). In particular, since they are viewed as independent guardians of shareholder wealth, the role of outside directors has received much attention. The different theories of corporate governance have conflicting views regarding the role of independent directors in ensuring that companies use resources in ways which maximise value (Adams et al., 2010). This influences their views on whether more independent boards lead to more effective corporate governance. While the evidence surrounding the influence of such directors on firm performance is mixed (Bhagat and Black, 2002; Dalton et al., 1998; Gillette, et al., 2008; Kumar and Sivaramakrishnan, 2008), there has been limited research of the influence of board independence on corporate strategy.

Research suggests that information asymmetry is the crucial factor concerning the effectiveness of boards (Holmstrom, 2005). Independent directors have less information than executive directors and the CEO. Ravina and Sapienza (2010) find evidence for such information asymmetry. Analysing the relative profitability of trades in firms' shares by inside / outside directors, they found that insiders earn higher returns, indicating they have privileged access to information.

Managerial hegemony theory argues that this asymmetry of information between the executive and independent directors prevents the latter from exercising a credible challenge to decisions. Consequently, corporate strategic decisions are taken by senior management without reference to the board. Boards are a legal fiction with no practical governance function. Boards exist to satisfy the requirements of corporate law, serve as an ally of management and provide legitimacy to the strategic decisions made by management (Hendry and Kiel, 2004; Pfeffer, 1972; Stiles, 2001; Stiles and Taylor, 1996). Much of the evidence in support of this perspective is dated (Mace, 1971), and, as time has gone on, descriptive studies have suggested greater board involvement in strategy (Hermalin and Weisbach, 1998; McNulty and Pettigrew, 1999; 
Zahra and Pearce, 1989). However, the limited number of econometric studies have been more equivocal (cf Datta et al., 2009; Chen et al., 2009).

Alternative theories do suggest a role for boards in decision-making. Agency theory proposes that self-interested managers pursue activities which conflict with the interests of shareholders (Jensen and Meckling, 1976). The separation of ownership and control in joint stock companies with dispersed ownership requires independent directors on boards who, while not directly participating in strategic decision-making, have a corporate governance role to oversee, monitor and discipline top management on behalf of shareholders, using the limited information available to them (Dominguiz-Martinez et al., 2008; Hillman and Delziel, 2003).

In this context, Adams and Ferrera (2007) develop a model where CEOs can influence the decisions of boards by controlling information released to independent directors about the viability of investment decisions, including diversification. Board independence is an important aspect of the model, influencing the CEOs incentive to share information about the payoffs from diversification. They demonstrate that if boards could take control over decisionmaking in all circumstances it is in CEOs interest to share the information. The important features of the model are the ability of a board to exert control and the personal cost this imposes on a CEO - they do not like losing control. Exerting control has a cost for boards, but this cost falls with greater board independence. More independent boards find it easier to confront CEOs and extract information. Consequently, more independent boards will protect shareholders' interests, constraining managers' pursuit of unrelated diversification and encouraging related diversification.

Stewardship theory provides a different view of the incentives of executive directors compared to agency theory (Davis et al., 1997). This perspective states that, as stewards of a corporation's resources, boards will take an active role in strategic decision-making (Forbes and Milliken, 
1999; Hung, 1998; Stiles, 2001). Managers are not motivated by extrinsic rewards, but “...a need to achieve, to gain an intrinsic satisfaction through successfully performing inherently challenging work. To exercise responsibility and authority...” (Donaldson, 1990, p. 375). Consequently, rather than shareholders' and mangers' goals diverging, they are congruent. Stewardship theory implies that it is executive directors, not independent directors who will have most to contribute to strategy, since they will have the knowledge, expertise and commitment which independent directors, constrained by time and resources, lack. Decisionmaking dominated by such directors will be in shareholders' interests and produce better performance (Muth and Donaldson, 1998). Unlike agency theory, stewardship theory argues that governance structures like the board of directors should be designed to empower rather than constrain managers. Stewardship theory favours smaller, less independent boards, giving executive directors more autonomy. Faced with more independent directors, executives are likely to have a reduced incentive to pay proper attention to decision-making. Indeed, the ambiguous relationship between board independence and firm performance that is observed in some research provides support for this view (Kumar and Sivaramakrishnan, 2008). The limited cross-sectional analysis conducted has found no evidence for this perspective (Chen et al., 2009).

The different theoretical perspectives - managerial hegemony, agency and stewardship predict a different relationship between board independence and the extent of unrelated corporate diversification. Since, the regulatory tide in the UK has flowed towards agency theory conceptions of the role of independent directors, this research will test hypotheses based on its propositions:

Hypothesis 1a: There is a negative association between board independence and the corporation's extent of unrelated diversification. 
Hypothesis 1b: There is a positive association between board independence and the corporation's extent of related diversification.

In contrast to the theories above, which focus on board independence, resource dependency theory focuses on interlocking directorships which link companies to competitors and other stakeholders (Fich and Shivdasani, 2006; Kiel and Nicholson, 2003). Such interlocks occur when a person affiliated with one corporation serves on the board of another corporation (Mizruchi, 1996). Interlocks may act as information pathways between corporations and provide useful information on a corporation's external business environments (Haunschild and Beckman, 1998). Consequently, the intra-industry and extra-industry ties of interlocking directors are expected to have different effects on corporations' types of diversification. Interlocking directors with intra-industry ties are likely to promote investments in areas they know about - related products and markets. On the other hand, interlocking directors with extra-industry ties could connect a corporation with broader investment opportunities, increasing the possibility of a board choosing to diversify across unrelated sectors (Daily and Dalton, 1993; Pfeffer and Salancik, 1978). This is echoed in recent work by Kaczmarek et al., (2014), who report that executives' extra-industry ties are associated with innovative strategies while executives' intra-industry ties are related to strategic conformity. Consequently, resource dependency theory suggests a positive association between the proportion of directors with extra-industry links and a corporation's level of unrelated diversification. Indeed, Chen et al. (2009) find a significantly positive association concluding that directors with extra-industry ties do act as information pathways promoting a corporate strategy involving significant unrelated diversification. While their research includes any ties, it can be argued that if the board members are independent directors in extra-industry corporations, they may face the same information asymmetries there. Therefore, it would be best to focus on those board 
members who have extra-industry executive directorships. Consequently, we propose to test the following hypothesis:

Hypothesis 2: There is a positive association between the proportion of interlocking board members with extra industry executive directorships and the extent of unrelated diversification.

Some proponents of agency theory predict that another type of director may also help overcome the asymmetric information in corporate decision-making and curb managerial opportunism (Stearns and Mizruchi, 1993). In the UK, financial institutions are important investors, holding a large proportion of the shares issues by corporations (Kay report, 2012). Kay related that an overwhelming proportion of shares in FTSE100 companies were held by financial institutions. Consequently, their trading decisions can have a big impact on corporations. Indeed, agency theory predicts that such institutions should have an incentive to monitor managers properly if their substantial block-holdings make the cost-benefit trade-off worthwhile. However, while such institutional investors control large amounts of equity, their holdings are well-diversified, meaning insignificant holdings in any one company. Therefore, such institutions have been assumed to be 'passive' rather than 'active' investors. Indeed, they may not see themselves as owners of corporate resources at all; equity is just another asset to be traded (Padgett, 2012).

However, there has been a long-standing view that institutional investors could be made more effective in governing corporations, with evidence indicating that active engagement does have a positive impact. For instance, both Brav, et al., (2008) and Clifford (2008) found that when hedge funds managers choose to follow an interventionist strategy in companies the financial performance of the latter was improved. Investigating the Chinese environment, Yuan et al. (2009) found that financial institutions played an active role, offsetting the issues relating to an immature regulatory environment as well as inadequate transparency and disclosure rules. 
They argued that such activism was absent in developed markets because of issues surrounding conflicts of interest and monitoring costs. However, financial institutions have informational and analytical advantages in monitoring management (Webb et al., 2003), and in the UK and other market-based governance jurisdictions, it has been recommended that institutional investors become more active stewards of companies rather than passive traders (Kay, 2012).

In the UK, such intervention tends to involve informal liaison with boards of the companies concerned. It does not involve formal representation on boards (Aguilera et al., 2006). However, it can be argued that, if a financial institution has an ownership block, their board representatives have an incentive to incur the monitoring costs needed to overcome information asymmetries associated with corporate boards and challenge management recommendations decisions (Duchin et al, 2010). Even if they do not represent any institutional ownership block, independent directors who are directors of financial institutional investors may have an insiders' knowledge and expertise, reducing monitoring costs and ensuring corporate decisions reflect shareholders' interests (Harris and Raviv, 2008).

Although there has been research into the impact of institutional ownership representation on corporate performance, there has been insufficient analysis of their impact on strategic decision-making. If they are an effective presence on boards, overcoming asymmetric information to resolve agency conflicts, then such institutional representatives should restrict the extent of value-destroying unrelated diversification and promote value-enhancing related product diversification. Chen et al. (2009) found that institutional representatives had no influence on the extent of unrelated corporate diversification, but that paper did not specify the nature of the institutional representation. We test the agency theory hypothesis regarding the influence of institutional representatives on boards: 
Hypothesis 3a: There is a negative association between the proportion of institutional ownership representatives on the corporation's board and its level of unrelated diversification.

Further, such institutional representation should support value-enhancing related diversification. Hence, the following hypothesis can be proposed:

Hypothesis 3b: There is a positive association between the proportion of institutional ownership representatives on the corporation's board and its level of related diversification.

\section{Research Method}

\subsection{Sample Selection}

We extend research into the impact of board characteristics on corporate diversification by testing the hypotheses stated in the previous section. Since the extent of corporate diversification will be the product of many decisions taken over a period of time and will take time to change in response to changes in the composition of a corporation's board, panel data analysis is appropriate. This approach captures not just differences across corporations, but also a dynamic element, relating changes in board composition to changes in the extent of product diversification. This will enable conclusions with reference to the hypotheses to be drawn.

We use a sample of 50 large UK Listed corporations with annual data for 11 years between 2005 and 2015. The sample is selected from the largest 250 companies by turnover for 2015 . Previous work tends to select on the basis of market capitalisation, but we adopt turnover, since this is a better reference to the size of a corporation in the context of diversification (Rumelt, 1982). Larger corporations were chosen because their management are more likely to face 
critical strategic decisions surrounding diversification, either related or unrelated. Further, they will tend to have the dispersed ownership structure that requires the delegation of decisionmaking to boards of directors. Consequently, these firms are appropriate to determine whether board characteristics influence product diversification. We excluded financial corporations because of the different structures of their balance sheets and their specialised measurement of diversification (Chen et al., 2009). The balanced panel dataset comprised 550 observations from a total of 50 companies.

\subsection{Data Collection and Variable Definitions}

The dependent variable is the level of corporate diversification. This paper focuses on product diversification. Product diversification measures the distribution of assets, sales and other indices across different industries (Beard and Dees, 1981). We add to existing work by distinguishing between unrelated and related product diversification. We use the distribution of sales revenue across different GISC industries to determine the extent of unrelated diversification using the Jacquemin and Berry (1979) entropy measure. We use the distribution of sales revenue across different product segments within the same GICS industry to determine the extent of related diversification using the same measure. The two measures are defined as follows:

Unrelated Product Diversification $(\mathrm{PD})=\Sigma_{1}\left[\mathrm{P}_{\mathrm{i}} \cdot \ln \left(1 / \mathrm{P}_{\mathrm{i}}\right)\right]$

Related Product Diversification $(\mathrm{GD})=\Sigma_{\mathrm{j}}\left[\mathrm{P}_{\mathrm{j}} \cdot \ln \left(1 / \mathrm{P}_{\mathrm{j}}\right)\right]$

Where $P_{i}$ is the proportion of total sales revenue attributed to unrelated industry sector "i", $P_{j}$ is the proportion of total sales revenue attributed to related industry segment " $\mathrm{j}$ ". $\ln \left(1 / \mathrm{P}_{\mathrm{i}}\right.$ or $\left.\mathrm{j}\right)$ is the weight given to each unrelated industry or related segment. The measure takes a value of zero where there is no product diversification and increases with the number of industries / segments reported. The higher the value, the greater the extent of product diversification. 
The diversification data were obtained from the Bloomberg Professional Software. This information was reported in accordance with the UK Accounting Standards Board, which reflect the requirements of IFRS 8 . While this was not introduced until 2009, all of the periods concerned are reported on Bloomberg in this way. A criticism of such segment reporting is that it may capture both related and unrelated product diversification, because the method of calculation is decided by the senior managers of the corporation. Previous work has assumed that segment reporting by corporations would reflect only unrelated activities and used this as the basis for calculating the extent of product diversification. However, in scrutinising corporate finance statements, we determine that many companies report product segments which are actually related. As a result, previous studies exaggerate the extent of unrelated product diversification conducted by corporations. Consequently, one of our empirical contributions to this field of literature is adopting a tighter definition of product diversification. We use the Bloomberg Professional software to identify which 2-digit Global Industrial Classification Standard (GICS) codes a corporation is included against; both primary activities and secondary activities. We cross-reference the reporting segments in a corporation's financial statements with these codes and allocate the different segments to the relevant 2-digit GICS code. For instance, a number of the companies only had a single 2-digit GICS code, yet reported multiple product segments. In contrast to previous work, our classification proposes that these corporations conduct no unrelated product diversification. Indeed, we assert that these firms are actually exploiting under-utilised resources across related product segments, which resource dependency theory suggests is beneficial to shareholders. We believe that such detailed research produces a more accurate reflection of the nature and extent of product diversification, revealing more meaningful results in relation to the proposed hypotheses about not only unrelated, but also, related diversification. 
Board data were collected from companies' annual reports, downloaded from the corporations' websites. Information on board composition, directors' affiliations and tenure were taken from the Report of the Board of Directors and Directors' biographies from the annual report. Data on affiliated companies were sourced from the Bloomberg Professional Software. Financial information and the segment reporting used to calculate product diversification were sourced from the Bloomberg Profession Software. The macroeconomic data on GDP were sourced from the Office of National Statistics (ONS) in the UK.

The independent variables in each of the three hypotheses, relating to board composition, are defined as follows. For hypotheses $1 \mathrm{a}$ and $1 \mathrm{~b}$, board independence is hypothesised as the proportion of independent directors on the board. Many prior studies have measured board independence using non-executive directors (see Muth and Donaldson, 1998). More recent revisions to corporate governance codes have tightened their definitions of independence. We adopt the definition of independence included in the relevant version of the UK Corporate Governance Code for each period. All corporations governed by the Code (including all those in the sample here) are expected to 'comply' with the code by having a majority of independent directors on the board or 'explain' their reasons for failing to comply. Indeed, some companies, while believing some of their directors to be independent, had to acknowledge that they weren't independent under the Code. In such circumstances, we determined that such directors were not independent. These statements, included in the corporate governance reports, enabled a more accurate measure of board independence than used in previous work.

For hypothesis 2, we count board members who were current executive directors of companies with different 2-digit GICS codes to the one which is the object of study. We only measure executive directorships since, such positions in affiliated companies, will be anticipated to provide the necessary expertise and credibility to help foster extra-industry investment. 
To determine the proportion of institutional representatives on the board of directors in order to test hypotheses $3 \mathrm{a}$ and $3 \mathrm{~b}$, we focused on directors who were current executive directors of financial institutions, since they would have full information about their company's activities. Even if they have no direct link with a company's institutional ownership blocks, independent directors who are executive directors of financial institutions may have an insiders' knowledge and expertise, reducing monitoring costs and ensuring corporate decisions reflect shareholders' interests. Hence, we include this measure of institutional representation to assess whether this insiders' knowledge has any influence on the extent of diversification - unrelated and related. Further, we tightened the definition of this variable to include only directors of financial institutions which held shareholdings in the corporation to assess whether it was ownership which was the key incentive to monitor properly.

The models include control variables representing board characteristics, size, leverage, free cash flow, liquidity, industry and general macroeconomic conditions. We include the proportion of board members representing other non-institutional ownership groups on the board (individual, family or state) as a control variable since these can influence board dynamics in decision-making (Hautz et al., 2013). Since, company CEOs are in a central position to influence board decisions, as their tenure lengthens, they can become more entrenched and less likely to pursue shareholders' interests (Hermalin and Weisbach, 1998). Therefore, we include CEO tenure as a control variable. Additionally, we include the average tenure of a company's independent directors in each period as a measure of their monitoring ability - the longer the average tenure, the more effective their monitoring.

Since larger companies are more able to diversify (Anderson et al., 2000; Ramaswamy et al., 2002), company size (TASSETS) is measured as the natural log function of total assets. Higher debt levels should be associated with higher levels of investment, funding growth. Therefore, leverage (LEV) is measured as the debt to total assets ratio. Liquidity (LIQ), measured as the 
current ratio (ratio of current assets to current liabilities), is a complementary measure to leverage (Gul and Leung, 2004). This is a proxy for the ability of a corporation to support high debt levels. It is expected to be positively related to the extent of diversification. Jensen (1986) argues that managers have an incentive to use free cash flow to undertake excessive diversification through value-destroying acquisitions in order to extend their control over resources. We measure free cash flow $(\mathrm{FCF})$ as net cash flow from operations plus interest paid plus net cash flows from investing activities.

Ramaswamy, et al., (2002) argue that industry membership is likely to play a role in determining the path of diversification a firm pursues through factors such as product differentiation, industry maturity and potential for synergies across supporting industries. Industry membership is included as a set of three categorical variables (these are related to the corporation's primary two-digit GICS code), to control for inter-industry differences in diversification levels. We also include the annual index level of UK GDP at constant prices $($ Base $=2012)$ to reflect the macroeconomic environment, since this may influence any changes to product diversification in any year. Table I shows a list of variable names and definitions.

\section{INSERT TABLE I HERE}

\subsection{Empirical Design}

Panel regression models are used to test the above hypotheses. Model 1 which is used to test hypotheses $1 \mathrm{a}$ and $1 \mathrm{~b}$, relates the diversification of the corporation to the proportion of independent directors on the board, as well as the control variables. 
DIV $=\beta_{0}+\beta_{1} \mathrm{PID}+\beta_{2} \mathrm{POWN}+\beta_{3} \mathrm{CEOT}+\beta_{4} \mathrm{IDT}+\beta_{5} \mathrm{LEV}+\beta_{6} \mathrm{LIQ}+\beta_{7} \mathrm{FCF}+\beta_{8} \mathrm{IND}+$ $\beta_{9} \mathrm{OUTPUT}+\varepsilon_{\mathrm{t}}$

Hypotheses 2 is tested using model 2, which relates total diversification to proportion of board members with extra-industry executive directorships on the board.

DIV $=\beta_{0}+\beta_{1}$ PER $++\beta_{2}$ POWN $+\beta_{3}$ CEOT $+\beta_{4}$ IDT $+\beta_{5}$ ASSETS $+\beta_{6}$ LEV $+\beta_{7}$ LIQ +

$\beta_{8} \mathrm{FCF}+\beta_{9} \mathrm{IND}+\beta_{10} \mathrm{OUTPUT}+\varepsilon_{\mathrm{t}}$

Hypotheses $3 \mathrm{a}$ and $3 \mathrm{~b}$ are tested using model 3 , which relates total diversification to proportion of institutional representatives on the board.

DIV $=\beta_{0}+\beta_{1} \mathrm{PIR}++\beta_{2} \mathrm{POWN}+\beta_{3} \mathrm{CEOT}+\beta_{4} \mathrm{IDT}+\beta_{5} \mathrm{ASSETS}+\beta_{6} \mathrm{LEV}+\beta_{7} \mathrm{LIQ}+$

$\beta_{8} \mathrm{FCF}+\beta_{9} \mathrm{IND}+\beta_{10} \mathrm{OUTPUT}+\varepsilon_{\mathrm{t}}$

For the three models, separate regressions were run for the two dimensions of diversification; unrelated and related product diversification.

For each firm, the dimensions of product diversification are measured using the Jacquemin and Berry (JB) statistic. In years where there is no product diversification the value of the dependent variable is censored at zero. Product diversification by firms, either unrelated or related results in a positive JB measure. In our data, there are a large number of observations with a zero value. There are 360 observations with a zero value for unrelated product diversification and 180 observations with a zero value for related product diversification. With this distribution, an OLS would yield biased and inconsistent parameter estimates. In order to ensure that the censured observations can be retained for analysis in order to produce valid results, a panel Tobit regression is used. This is normally used in situations where there are unobservable values of the dependent variable beyond a certain point, but is appropriate where there is a limited, but continuous dependent variable (McKnight and Weir, 2009). This is the case for 
our measures of the dependent variable. In the Tobit model, the observed value for the dependent variable (DIV) is distinguished as follows; 0 if DIV $=0$ (no diversification) and the $\mathrm{JB}$ measure if DIV> 0 (positive diversification). Parameters are then estimated by maximising the $\log$ likelihood function.

\section{Empirical Results}

\subsection{Descriptive Statistics}

Of the 50 companies in the sample, $34(68 \%)$ conducted no unrelated product diversification at any time over the period. Of the remaining 16, only 11 exhibited unrelated product diversification across the entire period. Figure I illustrates the mean JB measure for the subsample of firms who exhibited unrelated product diversification. The mean values across all the years are much less than previous studies (see Chen et al., 2009; Hitt et al., 1997). This may reflect our more restrictive definition for unrelated product diversification. The graph shows a declining trend across the period, arrested to some extent by the financial crisis of 2007-2009. The pattern is consistent with evidence of an increasing focus in corporate activities since the 1990s (Haynes et al, 2000).

A greater proportion of the sample conducted related product diversification (35 companies). 27 exhibited positive related product diversification across the whole period. Five companies moved from positive product diversification to none during the time period. The mean level of related diversification across the whole period is also higher compared to unrelated product diversification (0.8203 compared to 0.622). Figure II illustrates the mean JB statistic for the sub-sample of firms who exhibited related product diversification. There was a slight increase in the average across the period for this sub-group. 


\section{INSERT TABLE II HERE}

Descriptive statistics are provided in table II. The average proportion of independent directors is 0.5219 . There is a slight increase in the average proportion over the period reflecting greater compliance by firms to recent revisions of the UK corporate governance code. The average proportion of institutional representatives on the board is 0.0537 , which is very low. If the definition of institutional representation is tightened to include only directors who are executives of financial institutions with ownership interests, the mean falls to 0.007 . This is extremely low and changes very little across the period, suggesting little push to appoint such directors. Indeed, $16(32 \%)$ of the firms had no board members with institutional executive directorships in any year between 2005 and 2015. The average proportion of directors with extra-industry affiliations is 0.1274 . This is low and changes little across the period.

\section{INSERT TABLE III HERE}

Table III illustrates the correlation matrix for the dependent and independent variables. While significant collinearity exists between a several variable pairs, it is the one between the natural $\log$ of total assets (TASSETS) and the proportion of independent directors (PID) which impacts on the regression analysis. This supports the argument that larger firms will have more pressure to conform to Code requirements regarding the proportion of independent directors and do so. Consequently, these variables will be included in different regression models.

\subsection{Results from Estimations - Unrelated Product Diversification}


In order to analyse the impact of changes in board composition on the extent of unrelated product diversification over time, we conducted panel Tobit regressions. Table IV shows the results of the regression analysis. The effects of decisions to enter or leave product segments will take time to enact, so for all the models, a lagged estimation was used. We settled on 2 year lags since it would take time for board changes to influence decisions and further time for the changes to be enacted.

In relation to model 1 , the results indicate a significant relationship between the proportion of independent directors on the board and the degree of unrelated product diversification in a way which supports efficiency theory. The negative sign of the coefficient supports agency theory - a higher proportion of independent directors on boards leads to decreases in the extent of unrelated product diversification. Therefore, hypothesis 1a cannot be rejected.

\section{INSERT TABLE IV HERE}

For model 2, the coefficient on the proportion of board members with extra-industry directorships is insignificant. Hence, hypothesis 2 can be rejected - a higher proportion of directors with extra-industry links does not promote greater unrelated product diversification. This casts doubt on resource dependency theory and its conceptions of the influence of directors' expertise on corporate decisions.

Model 3 show no significant relationship between the proportion of institutional representatives on boards and the extent of unrelated product diversification. This does not suggest that board members with such expertise act to overcome information asymmetries between executive and independent directors on boards. Tightening the definition of this 
variable to incorporate only those directors representing institutions with ownership stakes has no impact on the results. Therefore, hypothesis $3 \mathrm{a}$ can be rejected.

In all of the models, the average tenure of independent directors had a significant influence on the extent of unrelated product diversification. The sign of the coefficient is negative, suggesting that as such board members gain more experience of companies as a group they may feel more confident to challenge executives' excessive diversification, forcing a retrenchment in the scope of activities. This supports agency theory. In addition, changes in the leverage ratio has a significantly positive coefficient in all of the models. Liquidity has a significantly negative influence on the extent of unrelated product diversification. This is inconsistent with previous work. The results indicate that those firms classified as industrials were more likely to have greater unrelated product diversification than those classified as consumer orientated.

\subsection{Related Product Diversification}

In order to analyse the impact of changes in board composition on the extent of related product diversification over time, we conducted panel Tobit regressions. As with unrelated product diversification, a lagged estimation was used since it would be expected that changes in independent variables would take time to influence the extent of product diversification. A lag of two years was used. Table $\mathrm{V}$ shows the results of the regression analysis.

In relation to model 1 , the results indicate a significant relationship between the proportion of independent directors on the board and the degree of related product diversification. The sign is positive indicating that a higher proportion of independent directors produces greater related product diversification. Therefore, hypothesis $1 \mathrm{~b}$ cannot be rejected. This supports agency theory propositions regarding the influence of independent directors on strategic decisions. It 
also supports efficiency theory since the relationship supports the view that more independent boards promote value-enhancing related diversification.

\section{INSERT TABLE V HERE}

For model 3, the results show a significant relationship between the proportion of institutional representatives on boards and the extent of related product diversification. However, the sign of the coefficient suggests that higher proportions of such board members actually produce lower levels of related diversification. This is not consistent with agency theory propositions. They may well act to maintain very narrowly focused enterprises. Tightening the definition of this variable to include directors representing institutions with ownership stakes has no impact on the results. Therefore, hypothesis $3 \mathrm{~b}$ can be rejected.

In all of the models, both debt and liquidity are significant influences on related product diversification. However, the signs are conflicting. Higher debt is associated with higher related diversification. In contrast, lower liquidity is associated with higher related diversification. The results indicate that industrial classification has a significant influence on the extent of related product diversification. Companies in the consumer sector are more likely to engage in related product diversification than industrials. In model 3 only, the coefficient for total assets is significantly positive, indicating that larger firms are more likely to engage in related diversification. In contrast, the coefficient for CEO tenure is significantly negative. This

suggests longer-serving CEOs are associated with lower levels of related product diversification.

\section{Implications of the Results}

The results show some limited support for the influence of board composition on corporate governance. Agency theory proposes that more independent boards are more likely to 
overcome information asymmetries between executive and independent directors, ensuring strategic decisions are consistent in promoting shareholders' interests in ways which supports efficiency theory. Firstly, 34 of the 50 companies in our sample conducted no unrelated product diversification across the period at all. Of the remaining 16 companies which did, the average level decreased across the period. Secondly, our regression results suggest that increases in the proportion of independent directors on corporate boards were associated with decreases in the extent of unrelated product diversification. Thirdly, our results also show that increases in the proportion of independent directors on corporate boards were associated with increases in the degree of related product diversification. Finally, our research disputes resource dependency theory since the proportion of board members with extra-industry executive directorships had no influence on changes in the extent of unrelated diversification.

Overall, the work suggests that the emphasis on board independence in corporate governance reform by the UK regulatory authorities may be appropriate. However, the observed association needs to be treated with caution. As listing requirements regarding board independence for UK corporations have tightened over the last decade, it would be expected that the proportion of such directors on UK boards would rise. This was indeed the case for our sample. Across all the companies in our sample, whether they conducted product diversification (unrelated and related) or not, there was an increasing proportion of independent directors on boards.

Our results indicate that directors with links to financial institutions do not influence the extent of unrelated product diversification, but do affect the extent of related product diversification - though not in the way proposed by agency theory. They do not help overcome information asymmetry in boards. Therefore, proposals to encourage the active involvement of such institution to ensure that resources are invested in a productive manner must be treated with caution. However, given the very low incidence of this type of director among the companies 
in our sample, it may be premature to draw firm conclusions. More work needs to be done analysing their impact on a variety of corporate decisions.

\section{Conclusions}

This paper adds to the literature surrounding the governance role of corporate boards of directors by exploring the link between board composition and corporate diversification. The paper makes a contribution to research in this area by testing several hypotheses based on innovations surrounding board dynamics involving information asymmetry. Given the emphasis on agency theory in regulatory reforms, the hypotheses propose relationships between different aspects of board composition which reflect its conceptions. Further, we develop a hypothesis testing resource dependency theory. Previous work focused on crosssectional analysis. We advance research by adopting a panel data analysis, tracing changes in board composition and corporate diversification over 11 years between 2005 and 2015 in a sample of large UK listed companies. This enabled the work to analyse differences across companies, but also analyse the dynamic relationships within companies over time. The results of this longitudinal study complement existing work by analysing how board changes over a number of years may influence strategic decisions. We also make a novel contribution by distinguishing between unrelated and related diversification and analysing the contrasting propositions about the influence of board composition on each. Consequently, we extend knowledge of the nature and extent of board involvement in ensuring resources are used effectively but, also provide evidence which can help guide corporate governance research and policy in the UK and similar jurisdictions.

The results are subject to limitations. The operationalisation of board independence is one limitation. The definition of an independent director changes with revisions to the UK corporate governance, and many companies stated in their reports that, even though certain 
directors do not qualify as independent under the Code, they were considered independent. Therefore, using the proportion of Code qualified independent directors on a board may not capture the full complexity of the concept. Further, despite the use of a panel of 50 large UK companies over 11 years, a large proportion exhibited no unrelated product diversification at all across the period, which means there are limits to the generalisability of the results. A broader study of UK firms may be beneficial. However, given the increasing trend for more narrowly-focused enterprises in developed corporate environments, analysing product diversification may not be a fruitful way of analysing the role of boards in strategy. The investigation of different types of strategic decisions may increasingly provide the variation in outcomes which yield useful results.

The definitions which have been used to determine board composition in this study are approximate measures of decision-making dynamics within boards of directors. To count as having institutional or extra-industry links, board members needed to be executive directors. Such a strict definition severely limited the incidence of such board members in our sample. It may be that looser definitions of directors' affiliations may capture the influences of these characteristics on strategy and provide a more meaningful measure for analysis. Further, emerging qualitative research investigating board dynamics may be more beneficial, particularly in relation to the influence of institutional representatives (Huse et al., 2011).

The results show that increased board independence advances the interests of shareholders by restraining unrelated corporate diversification and promoting related corporate diversification. This is consistent with the prevailing agency perspective that boards perform a monitoring role. Additionally, our results show that the average tenure of these independent directors has an important role to play. Longer average tenures promote changes in product diversification in line with shareholders' interests. This suggests that the regulatory drive for more board independence in the UK, and more widely, may resolve principal-agent conflicts in companies. 
However, one must be careful in drawing conclusions about the influence of independent directors on decision-making. The UK regulatory authorities must not rely on a single operationalisation of board independence. Board interactions are complicated. Our results suggest that in addition to appointing more independent directors to corporate boards, they must be appointed for periods of time which are sufficient to learn enough about the companies in order to overcome the asymmetric information they face, producing more effective monitoring and corporate governance.

\section{References}

Adams, R., Hermalin, B. and Weisbach, M. (2010) 'The role of boards of directors in corporate governance: A conceptual framework and survey'. Journal of Economic Literature, Vol. 48: pp.58-107.

Adams, R. and Ferreira, D. (2007) 'A theory of friendly boards'. Journal of Finance, Vol. 62: pp.217-250.

Adams R., Almeida, H. and Ferreira, D. (2005) 'Powerful CEOs and their impact on corporate performance'. Review of Financial Studies, Vol. 18: pp.1408-1432.

Aguilera, R., Williams, C., Conley, J. and D. Rupp (2006) 'Corporate governance and social responsibility: a comparative analysis of the UK and US'. Corporate Governance: an international review, Vol. 14: pp147-158.

Amihud, Y. and Lev, B. (1981) 'Risk reduction as managerial motive for conglomerate mergers'. Bell Journal of Economics, Vol. 12: pp.605-617.

Anderson, R., Bates, T. and Bizjak, J. (2000) 'Corporate governance and firm diversification', Financial Management, Vol. 30: pp.5-22. 
Beard, D. and Dess, G. (1981) 'Corporate-level strategy, business-level strategy, and firm performance'. Academy of Management Journal, Vol. 24: pp.633-88.

Bhagat, S. \& Black, B. (2002) 'The non-correlation between board independence and longterm firm performance'. Journal of Corporation Law, Vol. 27: pp.231-274.

Brav, A., Jiang, W., Thomas, R. and Partnoy, F. (2008) 'Hedge fund activism, corporate governance and firm performance'. Journal of Finance, Vol. 63: pp. 1729-1775.

Chen, R., Dyball, M. and Wright, S. (2009) 'The link between board composition and corporate diversification in Australia'. Corporate Governance: An International Review, Vol. 17: pp.208-223.

Chizema, A. and Kim, J. (2010) 'Outside directors on Korean boards: governance and institutions'. Journal of Management Studies, Vol. 47: pp.109-129.

Clifford, C. (2008) 'Value creation or destruction? Hedge funds as shareholder activists'. Journal of Corporate Finance, Vol. 14: pp.323-336.

Daily, C. and Dalton, D. (1993) 'Board of directors' leadership and structure: Control and performance implications'. Entrepreneurship Theory and Practice, 17: 65-81.

Dalton, D., Daily, C., Ellstrand, A. and Johnson, J. (1998) 'Meta-analytic reviews of board composition, leadership structure, and financial performance'. Strategic Management Journal, Vol. 19: pp.269-290.

Datta, D., Musteen, M. and Herrmann, P (2009) 'Board characteristics, managerial incentives, and the choice between foreign acquisitions and international joint ventures'. Journal of Management, Vol. 35: pp.928-953.

Davis, J., Schoorman, F. and Donaldson, L. (1997) 'Towards a stewardship theory of management'. Academy of Management Review, Vol. 22: pp.20-47. 
Dominguiz-Martinez, S., Swank, O. and Visser, B. (2008) 'In defense of boards'. Journal of Economics and Management Strategy, Vol. 17: pp.667-682.

Donaldson, L. (1990) 'The Ethereal Hand: Organisational Economics and Management Theory', Academy of Management Review, Vol. 15: pp.369-381.

Duchin, R. Matsusaka, J. and Ozbas, O. (2010) 'When are outside directors effective?' Journal of Financial Economics, Vol.96: pp195-214.

Fich, E. and Shivdasani, A. (2006) 'Are busy boards effective monitors'? Journal of Finance, Vol. 61: pp.689-724.

Financial Reporting Council (2016) UK Corporate Governance Code.

Finkelstein, S. and Hambrick, D. (1996) Strategic Leadership: Top Executives and their Effects on Organisations. Minneapolis/St Paul, MN: West Publishing Co.

Forbes, D. and Milliken, F. (1999)' Cognition and corporate governance: Understanding boards of directors as strategic decision-making groups'. Academy of Management Review, Vol. 24: pp.489-505.

Gillette, A., Noe, T. and Robello, M. (2008) 'Board structures around the world: an experimental investigation,' Review of Finance, Vol. 12: pp.93-140.

Goyal, V. and Park, C. (2002) 'Board leadership structure and CEO turnover'. Journal of Corporate Finance, Vol. 8: pp.49-66.

Graham, J., Lemmon, M. and Wolf, J. (2002) 'Does corporate diversification destroy value'? Journal of Finance, Vol. 57: pp.695-720.

Gul, F. and Leung, S. (2004) 'Board leadership, outside directors' expertise and voluntary corporate disclosures'. Journal of Accounting and Public Policy, Vol. 23: pp.351-79. 
Guo, R., Kruse, T., and Nohel, T. (2008) 'Undoing the powerful anti-takeover force of staggered boards'. Journal of Corporate Finance, Vol. 14: pp.274-288.

Harris, M. and Raviv, A. (2008) 'A theory of board control and size'. The Review of Financial Studies, Vol. 21: pp1797-1832.

Haunschild, P. and Beckman, C. (1998) 'When do interlocks matter? Alternate source of information and interlock influence'. Administrative Science Quarterly, Vol. 43: 815-44.

Hautz, J., Mayer, M. and C. Stadler (2013) 'Ownership identity and concentration: a study of their joint impact on corporate diversification'. British Journal of Management, Vol. 23: pp102-126.

Haynes, M., Thompson, S. and Wright, M. (2000) 'The determinants of corporate divestment in the UK'. International Journal of Industrial Organisation, Vol. 18: pp.1201-1222.

Hendry, K. and Kiel, G. (2004) 'The role of the board in firm strategy: Integrating agency and organizational control perspectives'. Corporate Governance: An International Review, Vol. 12: pp.500-520.

Hermalin, B. and Weisbach, M. (1998) 'The determinants of board composition'. RAND Journal of Economics, Vol. 19: pp.589-606.

Hillman, A. and Dalziel, T. (2003) 'Boards of Directors and Firm Performance: Integrating Agency and Resource Dependence Perspectives'. Academy of Management Review, Vol. 28, pp.383-396.

Hitt, M., Hoskisson, R. and Kim, H. (1997) 'International diversification: Effects on innovation and firm performance in product-diversified firms'. Academy of Management Journal, Vol. 40: pp.767-98. 
Holmstrom, B. (2005) 'Pay without performance and the managerial power hypothesis: a comment'. Journal of Corporation Law, Vol. 30: pp.703-713.

Hung, H. (1998) 'A typology of the theories of the roles of governing boards'. Corporate Governance: An International Review, Vol. 6, pp.101-111.

Huse, M, Hoskisson, R, Zattoni, A, Viganò, R (2011) 'New perspectives on board research: Changing the research agenda'. Journal of Management and Governance, Vol. 15: pp.5-28.

Jacquemin, A. and Berry, C. (1979) 'Entropy Measure of diversification and corporate growth'. The Journal of Industrial Economics, Vol. 4: pp.359-69.

Jensen, M. (1986) 'Agency costs of free-cash flow, corporate finance and takeovers'. American Economic Review, Vol. 76: pp.323-329.

Jensen, M. and Meckling, W. (1976) 'Theory of the firm: Managerial behaviour, agency costs and ownership structure'. Journal of Financial Economics, Vol. 3: pp.305-360.

Kaczmarek, S., Kimono, S. and Pye, A. (2014) 'Interlocking directorships and firm performance in highly regulated sectors: the moderating impact of board diversity'. Journal of Management and Governance. 18: 347-372.

Kaplan, S. and Minton, B. (2006) 'How has CEO turnover changed? Increasingly performance sensitive boards and increasingly uneasy CEOs'. NBER Working paper series, No. 12465.

Kay, J. (2012) 'The Kay review of UK equity markets and long-term decision-making'. Department for Business, Innovation and Skills, London.

Kiel, G. and Nicholson, G. (2003) 'Board composition and corporate performance: How the Australian experience informs contrasting theories of corporate governance'. Corporate Governance: an international review, Vol. 11:pp 189-205. 
Kumar, P. and Sivaramakrishnan, K. (2008) 'Who monitors the monitor? The effect of board independence on executive compensation and firm value'. Review of Financial Studies, Vol. 21: pp.1371-1401.

Lane, P., Cannella, A. and Lutbatkin, M. (1998) 'Agency problems as antecedents to unrelated mergers and diversification: Amihud and Lev reconsidered'. Strategic Management Journal, Vol. 19: pp.555-578.

Mace, M. (1971) Directors: Myth and Reality. Boston: Division of Research Graduate School of Business Administration Harvard University.

McKnight, P. and Weir, C. (2009) 'Agency costs, corporate governance mechanisms and ownership structure in large UK publicly quoted companies: A panel data analysis'. The Quarterly Review of Economics and Finance, Vol. 49: pp.139-158.

McNulty, T. and Pettigrew, A. (1999) 'Strategists on the board'. Organisational Studies, Vol. 20: $\mathrm{pp} .47-74$.

Mizruchi, M (1996) 'What do interlocks do? An analysis, critique, and assessment of research on interlocking directories'. Annual Review of Sociology, Vol. 22:pp271-98.

Montgomery, C. (1994) 'Corporate diversification'. The Journal of Economic Perspectives, Vol. 8: pp.163-78.

Muth, M. and Donaldson, L. (1998) 'Stewardship theory and board structure: contingency approach'. Corporate Governance: An International Review, Vol. 6: pp.5-28.

Nicholson, G. and Kiel, G. (2007) 'Can directors impact performance? A case-based test of three theories of corporate governance'. Corporate Governance: An International Review, Vol. 15: pp.585-608. 
O'Shannassy, T. (2010) 'Board and CEO practice in modern strategic-making: how is strategy developed, who is the boss and in what circumstances'? Journal of Management and Organisation, Vol. 16: pp.280-298.

Padgett, C. 2012 Corporate Governance: Theory and Practice, Basingstoke: Palgrave MacMillan.

Pfeffer, J. (1972) 'Size and composition of corporate boards of directors: The organization and its environment'. Administrative Science Quarterly, Vol. 17: pp.218-28.

Pfeffer, J. and Salancik, G. (1978) The External Control of Organisations: A Resource Dependence Perspective. New York: Harper and Row.

Ramaswamy, K., Li, M. and Veliyath, R. (2002) 'Variations in ownership behaviour and propensity to diversify: A study of the Indian corporate context'. Strategic Management Journal, Vol. 23: pp.345-58.

Ravina and Sapienza (2010) 'What do independent directors know? Evidence from their trading'. Review of Financial Studies, Vol.23: pp.963-1003.

Rumelt, R. (1982) ‘Diversification Strategy and Profitability’. Strategic Management Journal, Vol. 3, pp.359-369.

Shleifer, A. and Vishny, R. (1997) 'A survey of corporate governance'. Journal of Finance, Vol. 52: pp.737-83.

Stearns, L. and Mizruchi, M. (1993) 'Board composition and corporate financing: The impact of financial institution representation on borrowing'. Academy of Management Journal, Vol. 36: pp603-618.

Stiles, P. (2001) 'The impact of the board on strategy: An empirical examination'. Journal of Management Studies, Vol. 38: pp.627-650. 
Stiles, P. and Taylor, B. (1996) 'The strategic role of the board'. Corporate Governance: An International Review, Vol. 4: pp.3-10.

Tian, G. and Twite, G. (2011) 'Corporate governance, external market discipline and firm productivity'. Journal of Corporate Finance, Vol. 17: pp.403-417.

Walsh, J. and Seward, J. (1990) 'On the efficiency of internal and external corporate control mechanisms, Academy of Management Review, Vol. 15: pp.421-458.

Webb, R., Beck, M. and McKinnon, R. (2003) 'Problems and limitations of institutional investor participation in corporate governance', Corporate Governance: An International Review, Vol. 11: pp.65-73.

Yuan, R., Xiao, N. Jason, N. and Zou, J. (2009) 'The role of financial institutions in the corporate governance of listed Chinese companies'. British Journal of Management, Vol. 20: pp562-580.

Yermack, D. (1996) 'Higher market valuation of companies with a small board of directors'. Journal of Financial Economics, Vol. 40: pp.185-211.

Zahra, S. and Pearce, J. II (1989) 'Boards of directors and corporate financial performance: A review and integrative model, Journal of Management, Vol. 15: pp.291-334. 
Table I: Variable Names, Definitions and their Source

\begin{tabular}{|c|c|c|}
\hline $\begin{array}{l}\text { Variable } \\
\text { Name }\end{array}$ & Definition & Source \\
\hline DIV & $\begin{array}{l}\text { Measure of Diversification: Unrelated product } \\
\text { diversification (UPD) or related product } \\
\text { diversification (RPD) }\end{array}$ & $\begin{array}{l}\text { Author's calculations using } \\
\text { data from Bloomberg }\end{array}$ \\
\hline PID & $\begin{array}{l}\text { The proportion of independent directors on } \\
\text { the board }\end{array}$ & $\begin{array}{l}\text { Company Report of the } \\
\text { Directors }\end{array}$ \\
\hline PIR & $\begin{array}{l}\text { The proportion of institutional representatives } \\
\text { on the board: either executives of institutions } \\
\text { with ownership interests in the company or } \\
\text { executives of institutions (PIROWN), } \\
\text { irrespective of ownership (PIR). }\end{array}$ & $\begin{array}{l}\text { Company Report of the } \\
\text { Directors }\end{array}$ \\
\hline PED & $\begin{array}{l}\text { The proportion of board members with extra- } \\
\text { industry (different 2-digit GICS) executive } \\
\text { directorships). }\end{array}$ & $\begin{array}{l}\text { Company Report of the } \\
\text { Directors }\end{array}$ \\
\hline PNIOWN & $\begin{array}{l}\text { The proportion of board members } \\
\text { representing non-institutional ownership } \\
\text { interests }\end{array}$ & $\begin{array}{l}\text { Company Report of the } \\
\text { Directors }\end{array}$ \\
\hline CEOT & CEO tenure measured in years. & $\begin{array}{l}\text { Company Report of the } \\
\text { Directors }\end{array}$ \\
\hline IDT & $\begin{array}{l}\text { Average tenure of independent directors } \\
\text { measured in years }\end{array}$ & $\begin{array}{l}\text { Company Report of the } \\
\text { Directors }\end{array}$ \\
\hline TASSETS & $\begin{array}{l}\text { Natural logarithm of total assets of the } \\
\text { company }\end{array}$ & $\begin{array}{l}\text { Bloomberg Professional } \\
\text { Service }\end{array}$ \\
\hline LEV & $\begin{array}{l}\text { Leverage Ratio: Ratio of Long-term debt to } \\
\text { total assets of the company }\end{array}$ & $\begin{array}{l}\text { Bloomberg Professional } \\
\text { Service }\end{array}$ \\
\hline LIQ & $\begin{array}{l}\text { Current ratio: ratio of current assets to current } \\
\text { liabilities }\end{array}$ & $\begin{array}{l}\text { Bloomberg Professional } \\
\text { Service }\end{array}$ \\
\hline FCF & $\begin{array}{l}\text { Free Cash Flow: net cash flow from } \\
\text { operations plus interest paid plus net cash } \\
\text { flows from investing activities }\end{array}$ & $\begin{array}{l}\text { Bloomberg Professional } \\
\text { Service }\end{array}$ \\
\hline IND & $\begin{array}{l}\text { Categorical measure covering three industrial } \\
\text { sectors adapted using the primary 2-digit } \\
\text { GICS Code }\end{array}$ & $\begin{array}{l}\text { Bloomberg Professional } \\
\text { Service }\end{array}$ \\
\hline GDP & $\begin{array}{l}\text { Index of UK Gross Domestic Product at } \\
\text { constant prices }(2012-100)\end{array}$ & $\begin{array}{l}\text { Office of National Statistics } \\
\text { (ONS) }\end{array}$ \\
\hline
\end{tabular}


Figure I: Mean Jacquemin and Berry (JB) Statistic for Firms exhibiting Unrelated Product Diversification between 2005 and 2015

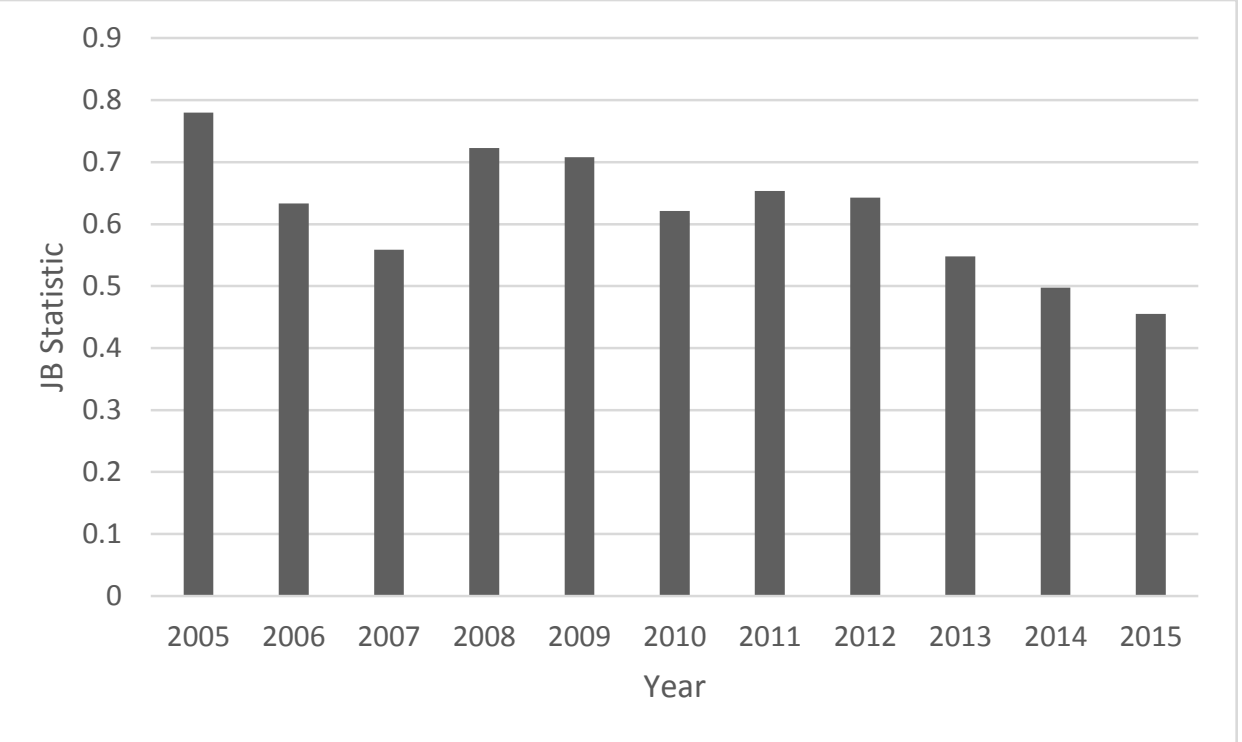

Figure II: Mean Jacquemin and Berry (JB) Statistic for Firms exhibiting Related Product Diversification between 2005 and 2015

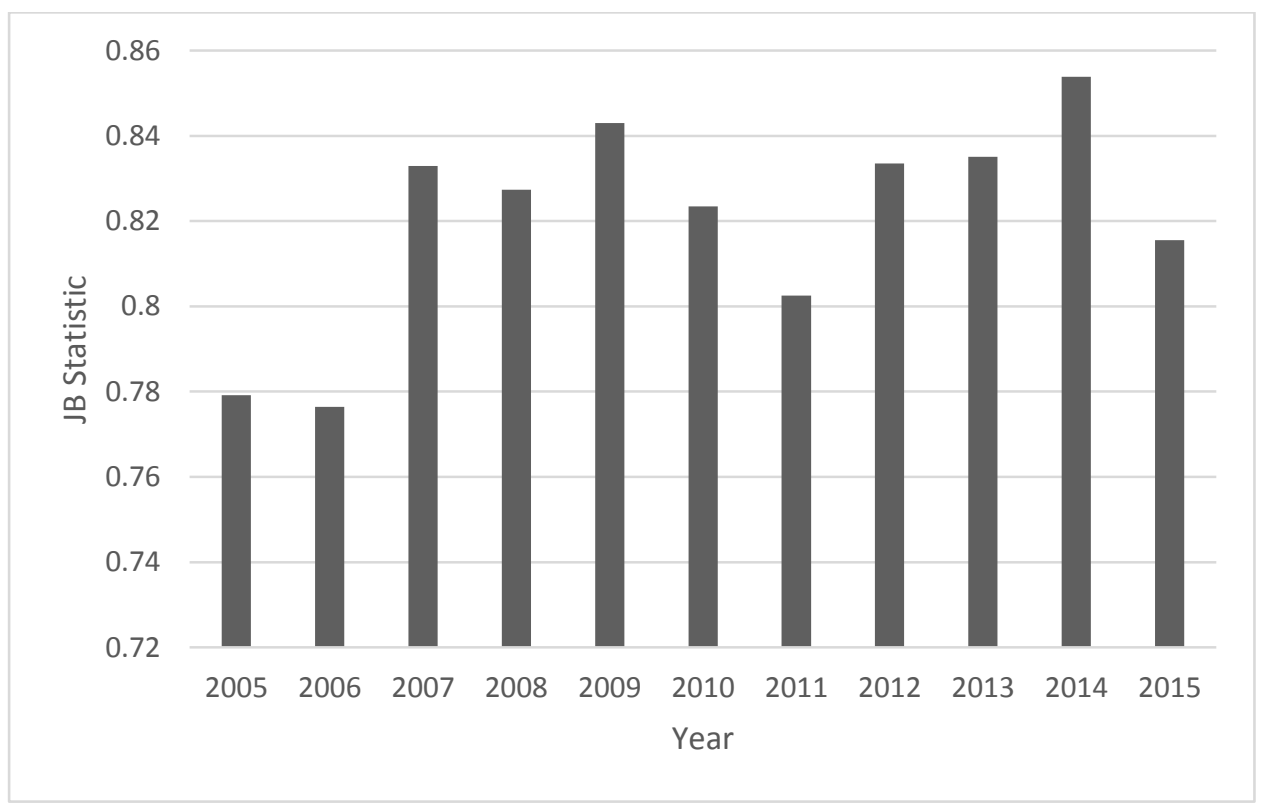


Table II: Descriptive Statistics

\begin{tabular}{|l|c|c|c|c|c|c|}
\hline & Mean & Median & Max & Min. & Std. Dev. & Observations \\
\hline UPD & 0.622 & 0.609 & 1.679 & 0 & 0.462 & 176 \\
\hline RPD & 0.820 & 0.707 & 1.900 & 0 & 0.454 & 385 \\
\hline PID & 0.522 & 0.500 & 0.846 & 0 & 0.125 & 550 \\
\hline PED & 0.127 & 0.111 & 0.571 & 0 & 0.122 & 550 \\
\hline PIR & 0.054 & 0.000 & 0.429 & 0 & 0.078 & 550 \\
\hline PIROWN & 0.007 & 0.000 & 0.167 & 0 & 0.027 & 550 \\
\hline PNIOWN & 0.021 & 0.000 & 0.250 & 0 & 0.053 & 550 \\
\hline CEOT & 5.1 & 4.0 & 33 & 0 & 4.99 & 550 \\
\hline IDT & 3.876 & 3.750 & 23.000 & 0 & 2.026 & 550 \\
\hline ASSETS & 7.865 & 7.920 & 11.097 & 2.915 & 1.320 & 550 \\
\hline LEV & 0.210 & 0.210 & 0.831 & 0 & 0.145 & 550 \\
\hline LIQ & 1.269 & 1.236 & 4.377 & 0.2264 & 0.568 & 550 \\
\hline FCF & 269.364 & 98.75 & 5750.00 & -3361 & 780.135 & 550 \\
\hline
\end{tabular}


Table III Pearson's Correlation Matrix

\begin{tabular}{|c|c|c|c|c|c|c|c|c|c|c|c|c|c|}
\hline Variables & UPD & RPD & PID & PIR & PED & PNIOWN & CEOT & IDT & SIZE & LEV & LIQ & FCF & OUTPUT \\
\hline UPD & 1 & & & & & & & & & & & & \\
\hline RPD & $-0.308 * *$ & 1 & & & & & & & & & & & \\
\hline PID & -0.160 & 0.098 & 1 & & & & & & & & & & \\
\hline PIR & -0.101 & -0.216 & 0.007 & 1 & & & & & & & & & \\
\hline PED & -0.012 & 0.207 & 0.091 & -0.146 & 1 & & & & & & & & \\
\hline PNIOWN & 0.068 & -0.030 & $-0.417^{* *}$ & -0.031 & -0.077 & 1 & & & & & & & \\
\hline CEOT & 0.169 & -0.040 & $-0.331 * *$ & 0.017 & -0.017 & $0.349 * *$ & 1 & & & & & & \\
\hline IDT & -0.154 & 0.026 & -0.030 & -0.020 & -0.077 & 0.072 & 0.003 & 1 & & & & & \\
\hline SIZE & 0.032 & 0.131 & $0.514^{* *}$ & 0.039 & 0.087 & -0.232 & -0.158 & 0.096 & 1 & & & & \\
\hline LEV & -0.012 & 0.062 & 0.020 & -0.134 & 0.082 & -0.092 & -0.125 & 0.050 & 0.077 & 1 & & & \\
\hline LIQ & -0.009 & 0.014 & 0.008 & 0.055 & 0.028 & -0.012 & -0.009 & -0.024 & 0.007 & -0.024 & 1 & & \\
\hline FCF & -0.001 & -0.005 & 0.248 & 0.150 & 0.096 & -0.125 & -0.034 & -0.007 & $0.364^{* *}$ & 0.056 & -0.007 & 1 & \\
\hline GDP & 0.054 & -0.019 & -0.246 & -0.033 & -0.107 & 0.030 & -0.105 & -0.019 & -0.170 & -0.050 & -0.074 & -0.019 & 1 \\
\hline
\end{tabular}

*indicates significance at 0.05 level

** indicates significance at 0.01 level 
Table IV: Panel Tobit Regression Results for Unrelated Product Diversification

\begin{tabular}{|c|c|c|c|}
\hline & $\begin{array}{c}\text { Model 1 } \\
\text { Panel Tobit } \\
\text { Regression }\end{array}$ & $\begin{array}{c}\text { Model 2 } \\
\text { Panel Tobit } \\
\text { Regression }\end{array}$ & $\begin{array}{c}\text { Model } 3 \\
\text { Panel Tobit } \\
\text { Regression }\end{array}$ \\
\hline Intercept & $1.721(1.452)$ & $-0.126(-0.107)$ & $-0.088(-0.076)$ \\
\hline PID (-2) & $-1.071(-2.165)^{*}$ & & \\
\hline PER (-2) & & $0.003(0.007)$ & \\
\hline PIR (-2) & & & $-0.803(-1.178)$ \\
\hline$\frac{\text { Control Variables }}{\text { PNIOWN }(-2)}$ & $-2.251(-1.970)^{*}$ & $-1.017(-0.941)$ & $-0.984(-0.93)$ \\
\hline CEOT (-2) & $0.012(1.039)$ & $0.02(1.93)^{*}$ & $0.021(2.008)^{*}$ \\
\hline IDT (-2) & $-0.207(-5.436)^{* *}$ & $-0.207(-5.363)^{* *}$ & $-0.205(-5.362)^{* *}$ \\
\hline LASSETS (-2) & & $0.058(1.337)$ & $0.061(1.422)$ \\
\hline $\operatorname{LEV}(-2)$ & $1.524(3.721)^{* *}$ & $1.658(4.065)^{* *}$ & $1.598(3.916)^{* *}$ \\
\hline LIQ (-2) & $-0.265(-3.005)^{* *}$ & $-0.266(-2.866)^{* *}$ & $-0.241(-2.69)^{* *}$ \\
\hline $\mathrm{FCF}(-2)$ & $3.16 e-05(0.436)$ & $-4.48 \mathrm{e}-05(-0.621)$ & $-3.43 e-05(-0.477)$ \\
\hline $\operatorname{GDP}(-2)$ & $-2.82 \mathrm{e}-03(-0.292)$ & $0.005(0.473)$ & $0.004(0.421)$ \\
\hline Industry & n.a & n.a. & n.a. \\
\hline Observations & 450 & 450 & 450 \\
\hline Companies & 50 & 50 & 50 \\
\hline Wald $\chi^{2}$ & 61.933 & 55.510 & 56.638 \\
\hline Log -Likelihood & -260.943 & -262448 & -261.742 \\
\hline
\end{tabular}

Coefficients of dependent variables shown (z-statistics are in parenthesis)

*indicates significance at 0.05 level

$* *$ indicates significance at 0.01 level 
Table V: Panel Tobit Regression Results for Related Product Diversification

\begin{tabular}{|c|c|c|}
\hline & $\begin{array}{c}\text { Model 1 } \\
\text { Panel Tobit } \\
\text { Regression }\end{array}$ & $\begin{array}{c}\text { Model } 3 \\
\text { Panel Tobit } \\
\text { Regression }\end{array}$ \\
\hline Intercept & $-0.803(-0.886)$ & $-0.211(-0.241)$ \\
\hline PID (-2) & $1.17(3.082)^{*}$ & \\
\hline \multicolumn{3}{|l|}{ PER (-2) } \\
\hline PIR (-2) & & $-2.246(-4.437) * *$ \\
\hline$\frac{\text { Control Variables }}{\text { PNIOWNR }(-2)}$ & $0.271(0.331)$ & $-0.294(-0.379)$ \\
\hline CEOT (-2) & $-0.015(-1.574)$ & $-0.022(-2.424)^{*}$ \\
\hline IDT (-2) & $0.003(1.443)$ & $0.026(1.203)^{*}$ \\
\hline LASSETS (-2) & & $0.08(2.465)$ \\
\hline $\operatorname{LEV}(-2)$ & $0.771(2.664)^{* *}$ & $0.505(1.793)$ \\
\hline LIQ (-2) & $-0.209(-2.837)^{*}$ & $-0.163(-2.246) * *$ \\
\hline $\mathrm{FCF}(-2)$ & $-2.89 \mathrm{e}-05(-0.628)$ & $-6.28 \mathrm{e}-07(-0.013)$ \\
\hline $\operatorname{GDP}(-2)$ & 7.5e-03 (1.011) & $0.003(0.463)$ \\
\hline Industry & n.a. & n.a. \\
\hline Observations & 450 & 450 \\
\hline Companies & 50 & 50 \\
\hline Wald $\chi^{2}$ & 30.297 & 44.447 \\
\hline Log -Likelihood & -466.806 & -458.058 \\
\hline
\end{tabular}

Coefficients of dependent variables shown (z-statistics are in parenthesis)

*indicates significance at 0.05 level

** indicates significance at 0.01 level 